\title{
A SEQUENTIAL IN-SITU HYBRIDISATION AND C-BANDING TECHNIQUE
}

\author{
J. HUTCHINSON* AND A. G. SEAL \\ Plant Breeding Institute, Maris Lane, Trumpington, Cambridge CB2 2LO, England \\ Received 6.xii.82
}

\section{INTRODUCTION}

C-banding has been widely used for identifying chromosomes and chromosome segments in plant and animal cells. However, the mechanisms of C-banding and its relationship to the structure of heterochromatin are poorly understood. Hybridisation of cloned DNA sequences to chromosomes in situ shows the chromosomal distribution of specific DNA sequences (reviewed by Hutchinson et al., 1981). A technique is described which combines these two procedures and has been used to compare directly, the distribution of a cloned highly repetitive DNA sequence with the distribution of $\mathrm{C}$-bands among chromosomes of rye.

\section{MATERials AND METHOdS}

(a) Plant material: Rye, Secale cereale cv. UC90 $(2 x=2 n=14)$ from the University of Manitoba, Canada. Chromosomes are numbered $1 \mathrm{R}$ 7R/4R according to Darvey and Gustafson (1975) and short and long arms are referred to by the letters $S$ and $L$ respectively.

(b) In situ hybridisation: Root tips were prepared and in situ hybridisation carried out as described by Hutchinson et al., (1980). After developing the autoradiographs, slides were stained in either Carbol Fuchsin stock solution (Darlington and La Cour, 1969) or 6 per cent aqueous Giemsa stain, then mounted in immersion oil.

(c) C-banding following in situ hybridisation: Coverslips were lifted off the slides and the immersion oil removed with diethyl-ether. After 15 mins at room temperature in Farmer's solution $(1.16 \mathrm{~g} / 1$ sodium thiosulphate and $7.4 \mathrm{~g} / 1$ potassium ferricyanide) to remove the silver grains, the slides were thoroughly washed in running tap water for $20 \mathrm{~min}$, transferred to acetic acid for $5 \mathrm{~min}$ at room temperature, passed through 70 per cent and 96 per cent ethanol and then air dried. After hydrolysis in $0.2 \mathrm{~N} \mathrm{HCl}$ for $1 \mathrm{hr}$ at room temperature the preparations were C-banded using Giemsa stain as described by Seal and Bennett (1981).

(d) Radioactive probe: The probe used was a tritium-labelled cRNA, transcribed from the plasmid pSC 210 (Bedbrook et al., 1980), containing a 480 b.p. highly repetitive sequence from rye.

\section{RESUlts AND DISCUSSION}

In situ hybridisation: All but one pair of chromosomes were labelled by the probe at one or both telomeres (fig. 1(a)). Some chromosomes were

\footnotetext{
*Present address: Department of Biological Sciences, Manchester Polytechnic, Manchester M1 5GD.
} 
labelled at distal interstitial sites. Predominantly telomeric labelling was expected in rye using this probe (Bedbrook et al., 1980).

C-banding following in situ hybridisation: When the same preparations were C-banded all chromosomes showed one or two telomeric bands (fig. 1(b)). Some chromosomes had faint interstitial bands.

In general, there was a close correspondence between the distribution of the label following in situ hybridisation and the distribution of C-bands on rye chromosomes. Moreover, higher grain counts were recorded over regions showing larger $\mathrm{C}$-bands. However, not all $\mathrm{C}$-banded sites were labelled by in situ hybridisation. The telomere of 4R/7RS which was clearly C-banded and the nucleolar organiser region of 1RS which was faintly banded (fig. 1(b)), showed no labelling with the probe (fig. 1(a)). A similar result was found in Rosner triticale and in a King II rye/Holdfast wheat addition line in which $4 R / 7 R S$ lacks the 480 b.p. sequence (Jones, 1980) but has a telomeric C-band (the comparison in this case was indirect, the C-banding and in situ hybridisation being done separately). Thus, the 480 b.p. repeated sequence is located at most but not all C-banded regions. This suggests that constitutive heterochromatin may contain more than one repetitive sequence. Indeed, several different repetitive sequence families in rye, isolated by molecular cloning, have been shown to be localised in the heterochromatic chromosome regions (Bedbrook et al., 1980; Appels et al., 1981).

Not all labelled sites were C-banded. For example, in fig. 1 (b) the telomere of $2 \mathrm{RL}$ is unbanded in one homologue and banded in the other, while both homologues are labelled in this region by in situ hybridisation (fig 1(a)). C-banding failure was in this case due to the disruption of chromusome structure by the sequential hybridisation and banding treatments, since other cells showed C-bands on both homologues in this region. Also, labelled sites on 5RL and 6RL were unbanded or faintly banded. Small C-bands are usually visible at these sites in preparations subjected to the C-banding technique alone.

Despite these limitations, the use of in situ hybridisation combined with C-banding provides a direct comparison of the distribution of C-banded heterochromatin and specific highly repeated DNA sequences. Such an approach is particularly useful when application of a probe alone does not permit chromosome identification but where this can then be achieved by $\mathrm{C}$-banding. Human and plant chromosomes have been banded by fluorochromes prior to in situ hybridisation (Evans et al., 1974; Deumling and Greilhuber, 1982). While this is a useful technique for chromosome identification, factors other than DNA sequence composition may cause variation in the banding patterns obtained with certain fluorochromes (Deumling and Greilhuber, 1982). The sequential Giemsa C-banding and in situ hybridisation technique described here will, therefore, provide further information on the structure of specific heterochromatic segments.

\section{REFERENCES}

APPELS, R.. DENNIS, E. S., SMYTH, D. R. AND PEACOCK, W. J. 1981. Two repeated DNA sequences from the heterochromatic regions of rye (Secale cereale) chromosomes. Chromosoma (Berl.), 84, 265-277.

BEDBROOK, J, R. JONES, J., O'DELL, M., THOMPSON, R. J. AND FLAVELL, R. B. 1980. A molecular description of telomeric heterochromatin in Secale species. Cell 19, 545-560. 

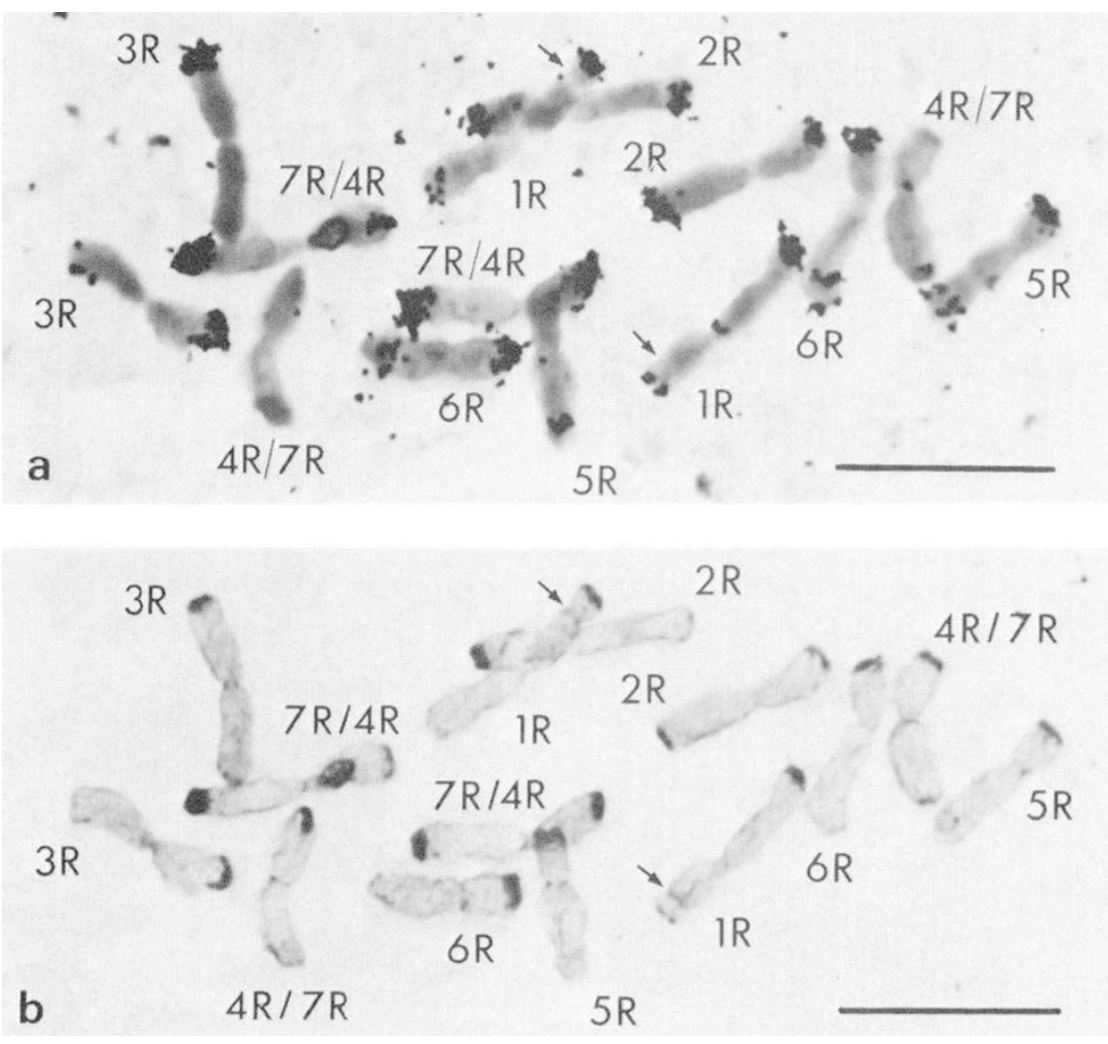

FIG. 1. Rye chromosomes (a) labelled by in situ hybridisation and (b) C-banded following in situ hybridisation. The nucleolar organiser region of $1 \mathrm{RS}$ is arrowed. $\mathrm{Bar}=10 \mu$. 
DARLington, C. D. AND LA COUR, L. F. 1969. The Handling of Chromosomes. Allen and Unwin, London.

DARVEY, N. L. AND GUSTAFSON, J. P. 1975. Identification of rye chromosomes in wheat-rye addition lines and triticale by heterochromatin bands. Crop Sci., 15, 239-243.

DEUMLING, B. AND GREILHUBER, J. 1981. Characterization of heterochromatin in different species of the Scilla siberica group (Liliaceae) by in situ hybridization of satellite DNAs and fluorochrome banding. Chromosoma (Berl.), 84, 535-555.

EVANS, H. J., BUCKLAND, R. A. AND PARDUE, M. L. 1974. Location of the genes coding for $18 \mathrm{~S}$ and $28 \mathrm{~S}$ ribosomal RNA in the human genome. Chromosoma (Berl.) 48, 405-426.

HUTCHINSON. J., CHAPMAN, V. AND MILLER, T. E. 1980. Chromosome pairing at meiosis in hybrids between Aegilops and Secale species: a study by in situ hybridisation using cloned DNA. Heredity, 45, 245-254.

HUTCHINSON, J., FLAVELL, R. B. AND JONES, J. 1981. Physical mapping of plant chromosomes by in situ hybridisation. In Setlow, J. and Hollaender, A. (eds.) Genetic Engineering, Vol. 3, Plenum Press, New York, pp. 207-222.

JONES, J. D. G. 1980. Repeated DNA sequences in rye (Secale cereale), wheat (Triticum aestivum) and their relatives. Ph.D. Thesis, University of Cambridge.

SEAL, A. G. AND BENNETT, M. D. 1981. The rye genome in winter hexaploid tritcales. Can. J. Genet. Cytol., 23, 647-653. 